\title{
A BREEDING RECORD OF THE STARLING AT LOOKOUT POINT, NORTHWEST TERRITORIES
}

\author{
by Ernie Kuyt, Fort Smith, N.W.T.
}

Since the first successful introductions in New York's Central Park in 1890 and 1891, the Starling (Sturnus vulgaris) has become established in many areas in North America. Northward dissemination has also taken place, but generally speaking, Starlings have not yet been noticed in northern Canadian. settlements in such numbers as in U.S. cities. In addition to the difference in size and numbers between our settlements and those to the south and consequent differences in potential bird populations, Starlings in our area are migratory and are only seen during part of the year. The first record of the Starling in the Northwest Territories was reported by W. A. Fuller who found a dead Starling 26 miles west of Fort S.mith on April 27, 1954 (Can. FieldNat., 69:27). In recent years they have appeared more frequently at Fort Smith. At the time of writing (September 8, 1964) they appear to have already left the area. The birds arrive from the south in April. Mr. Earl Gordon of the Wood Buffalo Park Warden Staff told me that on April 8, 1964, he had seen a small flock of Starlings feeding on meat scraps at the Hay Camp abattoir about 40 miles south of Fort Smith, N.W.T. On April 12, I saw a flock of 15 Starlings feeding in a vacant lot near the local hatel. In recent years, Starlings have also appeared in Yellowknife, N.W.T., about 200 miles north of Fort Smith, but there, as in other northern communities, their stay is only seasonal.

If we consider the immense mainland area north and east of a line drawn through Coppermine on Coronation Gulf, Yellowknife, Fort Smith, Stony Rapids and Churchill on Hudson's Bay and if we exclude a narrow coastal strip, we will find only a dozen or so small permanent settlements. Practically all of the mainland tundra regions fall within the area outlined. Lookout Point on the Thelon River occupies a central location in this huge area and is situated about 225 miles from the nearest two settlements (Baker Lake to the ENE and Fort Reliance to the SW). The closest settlements more in line with a possible north-south bird migration route are Fond-du-Lac and Stony Rapids, Saskatchewan, both about 350 miles to the south, but the Starling has not been reported in northern Saskatchewan.

On May 27, 1958, A. L. Wilk observed a Starling near Mosquito Lake, N.W.T., about 250 miles north of Stony Rapids. Mosquito Lake is well north of the tree line. On June 18, 1961, at Lookout Point, N.W.T., R. R. Taylor showed me the wings of a Starling which he had found at the entrance of a weasel burrow.

On June 16, 1964, I found the nest of a Starling in a box on our foodstage at Lookout Point. As I had not yet seen the parents, there was considerable doubt in my mind as to what bird had selected our foodstage for a nesting platform. I at first attributed the nest to Robins (Turdus migratorius) which also nest in the Lookout Point area. It wasn't until June 20 that I finally saw one of the parents long enough to determine its identity. Both parents were extremely shy, a characteristic also noticeable in the local Robins.

When first found at 6:00 p.m. on June 16, the nest contained four plain, pale bluish-green eggs. The nest itself was an untidy affair consisting of a handful of Willow Ptarmigan feathers and a few stalks of dry grass stuffed in the corner of a box containing oil cans. The foodstage, where food and oil are kept to safeguard them from grizzly bears, is about 15 feet high.

On June 22 at 6:00 p.m. one egg had just hatched and the following morning at 11 a.m. all four young had hatched. On July 1 the smallest of the young was found dead on the bottom of the nest. The dead bird was removed. The other three were lively and seemed to be thriving. No other visits were made until July 7 although the parent birds were seen occasion- 
ally. On the latter date a check revealed that all three young had died, apparently one or two days previously. The young were feathered out quite well and had grown considerably since the previous visit on July 1 . The stomachs of the young were filled with caterpillars and spiders. Night temperatures during the birds' last week of life did not dip below $45^{\circ} \mathrm{F}$. and only occasional rain-showers fell during that period.

The parents were not seen again after July 7 and the reasons for the failure of the nesting remains somewhat of a mystery. From this record it appears that Starlings may also expand their breeding range into unsettled regions.

\section{UNUSUALLY LARGE BROOD SIZE OF THE SAW-WHET OWL}

\author{
by Spencer G. Sealy, Edmonton
}

On May 7, 1964, while walking through a fairly dense growth of black poplar and willow bordering a dry slough bottom five and one-half miles southeast of Battleford, Saskatchewan, I came upon what looked to me like an ordinary deserted flicker hole in a dead poplar stump some eight feet from the ground. As usual I tapped the trunk, but this time to my surprise two large eyes in the head of a Saw-whet Owl (Acgolius acadicus) appeared at the entrance - thus providing my first nesting record for this species in the Battleford area.

Desiring to investigate the situation further I proceeded to find out what was in the nest. To my surprise and amazement I pulled out nine young of various sizes. The average clutch size for this species as given by Bent in his Life Histories of North American Birds of Prey (1961:232), and by other authors, is five or six young. In a subsequent survey of the literature I was unable to find a recording of a clutch of more than seven for this species.

\section{UNUSUAL NEST SITE OF A HORNED LARK \\ by Gary Anweiler, Melville}

In the summer of $1964 \mathrm{I}$ was shown a recently vacated nest of a Horned
Lark on the back lawn of Mr. Jack Hanowski in the residential section of Melville. The nest was located in a weedy part of the lawn which is about 20 by 70 feet and which is enclosed by a six-foot board fence. The lawn was used and cut regularly over the nest, but in spite of this two young fledged at the end of July. I examined an egg which had been taken from the nest (one of the three laid) and based my identification on this as well as on the nest. This nest site is even more unusual inasmuch as there is a piece of prairie adjacent to the yard which would have provided more suitable nesting cover. Note that in the same season three young Horned Larks fledged from a nest in a newly planted lawn in Saskatoon (Blue Jay, 23:14).

\section{RECORD OF A WOOD DUCK AT ITUNA}

by Mrs. Mary F. Brennan, Ituna

In my informal account in the last Blue Jay of the pleasures of bird watching here at our farm, I mentioned a record of the Wood Duck. At the request of the editors I have gone back to my notes for the particulars of this observation. The entry for May 27, 1955, reads: "Had a real thrill today. On a walk along the north road saw two very beautiful but unfamiliar ducks. When I came home and studied the bird books, they were, without a doubt, wood ducks."

I remember the occasion well; it was a lovely spring day, and the small sloughs and willow-circled potholes along the road were still full from the spring run-off, and it was in one of these that the two ducks were swimming. I think, but at this late date, am not positive, that they were a pair, male and female.

\section{WATCH FOR YELLOW-DYED GULLS}

Early in May of this year 80 Ringbilled Gulls and two California Gulls were colored a bright yellow with a harmless dye, then banded and released near Fort Collins, Colorado. This study of gull migration is being carried out by Professor Ronald A. Ryder, Dept. of Forest Recreation and Wildlife Conservation, Fort Collins, to whom sightings of yellow gulls should be reported. 